\title{
THE HANDMAIDS OF JACOB'S STORY IN THE CONTEXT OF CHRISTIAN ART
}

\author{
ว॰ส \\ HRİSTIYYAN SANATI BAĞLAMINDA \\ YAKUP HIKKAYESI'NDEKİ CARIYYELER
}

Pınar SERDAR DINÇER*

\begin{abstract}
$\underline{\text { Abstract }}$
A related issue addressed in this research is whether or not these handmaids in the Jacob story, who are depicted in Christian art as playing important roles and holding crucial positions in the family, are biblically more important to both the narrative and the family than has traditionally been recognized. Because of the importance of the historical context, the story of Zilpah and Bilhah is a remarkable myth for females and may be viewed as a master archetype of the age-old infertility problem. This raises of the question of how handmaids were defined in the Bible. In the study, examples of Christian art were included with the Bible commentary. Consequently, identifying the handmaids is only possible by following the chronological sequence of events in Genesis. This study also shows the identify of handmaids in the biblical book of Genesis. Besides the Bible, rabbinic sources were also investigated in detail. It is possible that children may have increased the status of women in Genesis but this is only true of women who already had status to speak of.
\end{abstract}

Keywords: Handmaid, Jacob, Christian art, Zilpah, Bilhah,

\section{$\underline{\mathbf{O}_{\mathbf{z}}}$}

$\mathrm{Bu}$ araştırma aile içinde önemli bir pozisyona sahip olan Yakup hikayesindeki cariyelerin (Zilpa ve Bilha) Hıristiyan Sanatı'nda nasıl tasvir edildikleri ile ilgilidir. Söz konusu cariyelerin (Zilpa ve Bilha) varolmasinda Kutsal Kitaptaki hikayelerin mi yoksa bilinen geleneksel ailelerin rolünün etkin olup olmadığı araştırmanın bir diğer konusudur. Tarihsel bağlamın önemi nedeniyle Zilpa ve Bilha'ın hikâyesi kadınlar için kayda değer bir mitdir ve süregelen infertilite (kısırlık) probleminin arketipleri olarak görülebilir. Bu durum cariyelerin Kutsal Kitap’ta nasıl tanımlandığı sorusunu gündeme getirir. Araştırmada, Hıristiyan sanatından özellikle Bizans Sanatı'ndan örneklere Kutsal Kitap yorumlasılya birlikte yer verilmiştir. Ancak cariyeleri sanat eserlerinde tanımlamak, Kutsal Kitap’taki Yaratılış metnindeki olayların kronolojik sıralamasını izleyerek mümkün olmuştur. Söz konusu çalışma, Kutsal Kitap'taki Yaratılış bölümünde bahsi geçen cariyelerin nasıl tanımlandıklarını da göstermektedir. Konuyla ilgili kaynak olarak Kutsal Kitap dışında

\footnotetext{
* Dr. Öğr. Üyesi. Bozok Üniversitesi, Fen-Edebiyat Fakültesi, Sanat Tarihi Bölümü, Yozgat.

ORCID ID: 0000-0003-4152-6327 • E-mail: pinar.serdar@bozok.edu.tr
} 
rabinik kaynaklar da detaylı bir biçimde araştırılmıştır. Bununla birlikte Yaradılış'da söz edilen çocukların, kadınların (annelerinin) statüsünü arttırmış olmaları muhtemeldir, ancak bu durum sadece belli bir statüye sahip kadınlar için geçerli olduğu görülür.

Anahtar kelimeler: Cariye, Yakup, Hıristiyan sanatı, Zilpa, Bilha,

\section{INTRODUCTION}

In this article I propose to take up the question of handmaids in Jacob's story from a rather eclectic viewpoint. Each figure in Jacob's family must be studied individually. (Table 1) The truly neglected women in the narratives are Zilpah and Bilhah, the handmaids of Leah and Rachel respectively. They are the ones for whom no death notice is given and no burial place recorded.

The tradition of providing a surrogate for the wife in the case of infertility was apparently so common that, in some relationships, provisions for it were made part of the primary marriage agreement. Laban gives each of his daughters with handmaids on the occasions of each of their marriages to Jacob. Their later use as surrogates shows that this may have been one of their assumed duties as female maidens ${ }^{1}$.

Three different types of wives are identified in the patriarchal family in the Old Testament: The primary wife, the wife's handmaid and the husband's concubine. The primary wife usually belonged to the same social class as her husband and had certain rights that were written into her marriage agreement. She usually carried at least one handmaid into the marriage, who was to act as a surrogate for her mistress in the event the mistress could not produce an heir for her husband. It was also an apparently ordinary practice for the husband to take a concubine. This secondary wife, in the normal cause of events, did not get a status equal to that of the primary wife. She sometimes lived with her husband and sometimes stayed in her own family's home ${ }^{2}$.

By retaining their identity, despite their lack of privileges and the anonymity of their gravesites, these matriarchs serve as a reminder of the expanding nature of the promise, ${ }^{3}$ in constant tension with the limitations imposed by proper marriage and family alliances ${ }^{4}$.

1 Spanier, 1989, 64-65.

2 Spanier, 1989, 91.

3 According to Genesis, the promise to the ancestors (Abraham, Isaac, and Jacob) consisted of three parts: land, offspring and blessing. This refers specifically to the promise of offspring.

4 Leonhardt, 2004, 85. 


\section{ZILPAH and BILHAH in SEPTUAGINTA}

Leah $^{5}$ and Rachel were Laban's daughters; both married Jacob. Jacob loved Rachel, but he was forced to marry Leah when his uncle, Laban, tricked him. Following middle eastern marriage customs ${ }^{6}$, Laban gave Zilpah ${ }^{7}$ to Leah as a handmaiden when he gave Leah to Jacob as a bride. Zilpah is first introduced in the Bible in Genesis 29:248. Laban gave Bilhah ${ }^{9}$ to Rachel as her handmaiden when he gave Rachel to Jacob as a bride. Bilhah was first introduced in the Bible in Genesis 29:2910. It is important to point out that Bilhah and Zilpah never speak themselves. Instead, either the author of Genesis or one of the other characters speak about them.

While Rachel battled many years of infertility, Leah bore Jacob four sons. Frustrated by infertility ${ }^{11}$ and anxious to give children to Jacob, Rachel offered her maid Bilhah to Jacob as a surrogate. As it is recorded in Genesis 30:1-8 ${ }^{12}$, Bilhah gave birth to Dan and Naphtali. After Leah had borne Jacob four sons, she offered Zilpah to Jacob as a surrogate so she could have more children for Jacob. Zilpah bore two sons, Gad and Asher, to Jacob. The explanation of Zilpah's role as Leah's surrogate can be found in Genesis 30:9-13. ${ }^{13}$

5 Leah is the oldest of the two daughters of Laban, the brother of Rebekah. She enters the narrative as the counterpoint to her beautiful and beloved sister Rachel. When Jacob completes his seven years of service to Laban in exchange for Rachel, Laban switches brides on Jacob's wedding night. Jacob agrees to complete the required seven nights with Leah, and then take Rachel as his second wife in exchange for seven more years of service.

6 Block, 2003, 78.

7 Meaning of Zilpah: Aggregatio. Gathering together; dripping; contempt of the mouth (Potts, 1922, 252)

8 Genesis 29:24: And Laban gave to his daughter Lea, Zelpha his handmaid, as a handmaid for her.

9 Meaning of Bilhah: Terror. Terror; alarm; timid (Potts, 1922, 58.)

10 Genesis 29:29: And Laban gave to his daughter his handmaid Balla, for a handmaid to her.

11 For further reference about 'old-age' infertility in the ancient world see Moss \& Baden, 2015.

12 Genesis 30:1-8: 1 And Rachel having perceived that she bore Jacob no children, was jealous of her sister; and said to Jacob, Give me children; and if not, I shall die. And Jacob was angry with Rachel, and said to her, Am I in the place of God, who has deprived thee of the fruit of the womb? And Rachel said to Jacob, Behold my handmaid Balla, go in to her, and she shall bear upon my knees, and I also shall have children by her. And she gave him Balla her maid, for a wife to him; and Jacob went in to her. And Balla, Rachel's maid, conceived, and bore Jacob a son. And Rachel said, God has given judgment for me, and hearkened to my voice, and has given me a son; therefore she called his name, Dan. And Balla, Rachel's maid, conceived yet again, and bore a second son to Jacob. And Rachel said, God has helped me, and I contended with my sister and prevailed; and she called his name, Nephthalim.

13 Genesis 30:9-13: And Lea saw that she ceased from bearing, and she took Zelpha her maid, and gave her to Jacob for a wife; and he went in to her. And Zelpha the maid of Lea conceived, and bore Jacob a son. And Lea said, It is happily: and she called his name, Gad. And Zelpha the maid 
Table 1: The Family of Jacob.

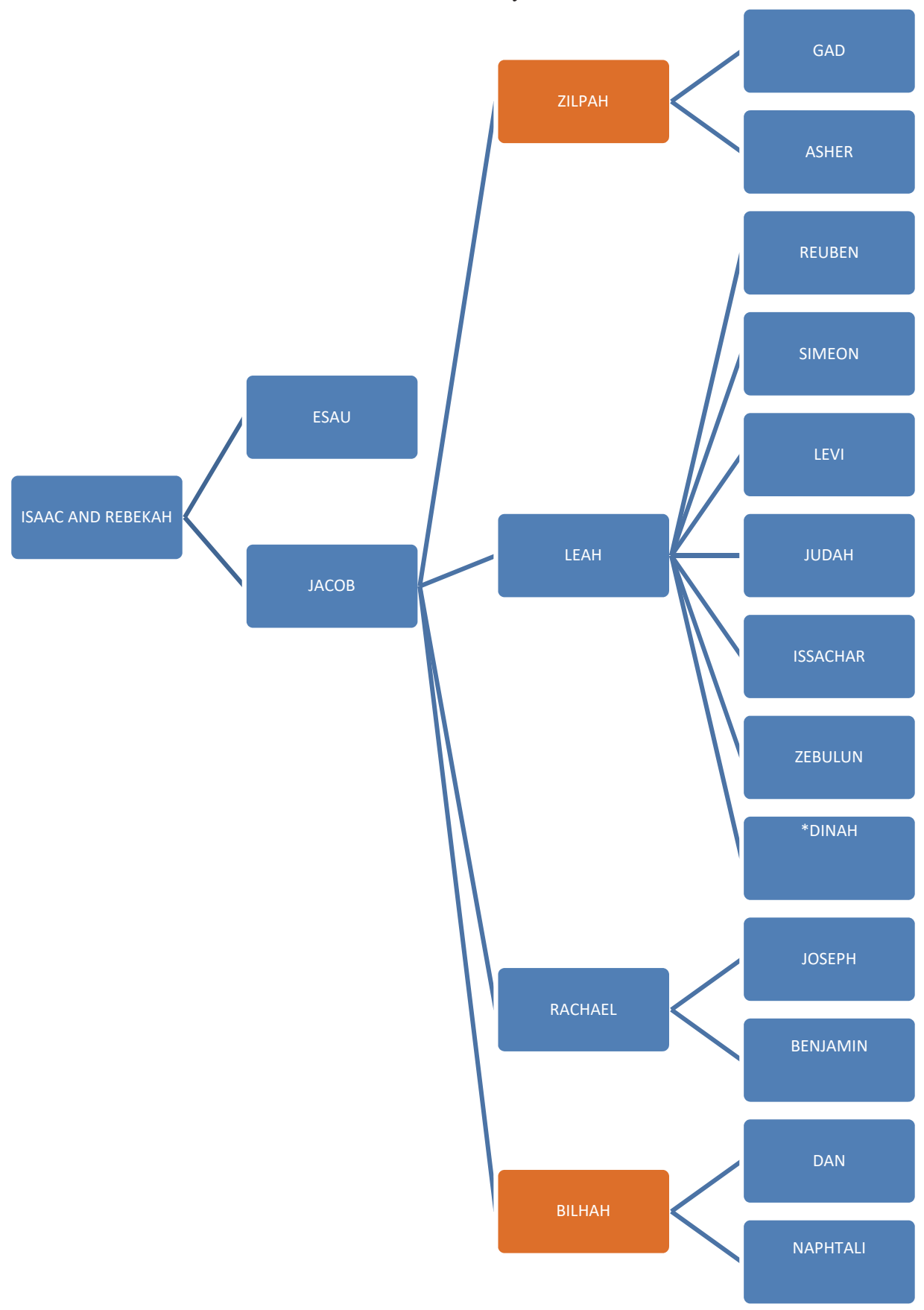


All of these was fueled by jealousy that caused an ongoing competition between Leah and Rachel.

Five chapters later in Genesis 35:214, Bilhah was mentioned when Jacob's firstborn son Rueben slept with her. This act caused Reuben to lose his birthright inheritance as recorded in Genesis 49:3-4 ${ }^{15}$. What's more, Bilhah birthed two of the twelve leaders of the tribe of Israel. Genesis $49: 16-17^{16}$ and $21^{17}$ mentions the blessings that Dan and Naphtali bring to the tribe of Israel.

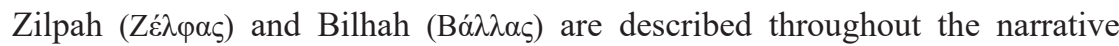

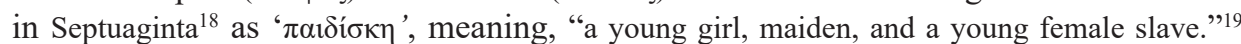

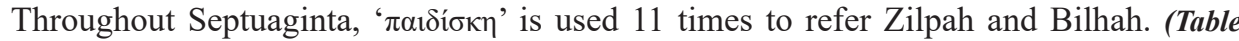
2) 'П $\alpha 1 \delta i ́ \sigma \kappa \eta '$ is also used to reference Hagar, the handmaid of Abraham's wife Sarah, throughout Genesis $16 .{ }^{20}$

Rachel and Leah gave their maids to Jacob as wives (see Genesis 30:421 and 30:922). The original Hebrew word ' $\gamma v v \alpha \tilde{\mathrm{i} \kappa} \alpha$ ' can be translated as both wife and woman. If translated as wife, this arrangement created an ambiguous relationship for both Bilhah and Zilpah with Jacob because, when a maid was given to a man as his wife, it was uncertain whether it was temporary or permanent.

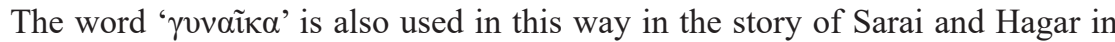
Genesis 16 . In this story, the ambiguity regarding the status of a maid once she had borne a child on behalf of her mistress is possibly why Hagar "looks down upon her mistress"

of Lea conceived yet again, and bore Jacob a second son. And Lea said, I am blessed, for the women will pronounce me blessed; and she called his name, Aser.

14 Genesis 35:21: And it came to pass when Israel dwelt in that land, that Ruben went and lay with Balla, the concubine of his father Jacob; and Israel heard, and the thing appeared grievous before him.

15 Genesis 49:3-4: Ruben, thou art my first-born, thou my strength, and the first of my children, hard to be endured, hard and self-willed. Thou wast insolent like water, burst not forth with violence, for thou wentest up to the bed of thy father; then thou defiledst the couch, whereupon thou wentest up.

16 Genesis 49:16-17: Dan shall judge his people, as one tribe too in Israel. And let Dan be a serpent in the way, besetting the path, biting the heel of the horse (and the rider shall fall backward)

17 Genesis 49:21: Nephthalim is a spreading stem, bestowing beauty on its fruit.

18 Wevers, 1974, 280.

19 Liddell \& Scott, 1901, 1107.

20 Wevers, 1974, 174.

21 Genesis 30:4: And she gave him Balla her maid, for a wife to him; and Jacob went in to her.

22 Genesis 30:9: And Lea saw that she ceased from bearing, and she took Zelpha her maid, and gave her to Jacob for a wife; and he went in to her. 
Table 2: Zilpah and Bilhah in Genesis.

\begin{tabular}{|c|c|c|}
\hline & Genesis Chapter / Verse & $\begin{array}{l}\text { Used to reference in } \\
\text { Septuaginta, Genesis }\end{array}$ \\
\hline Zilpah & $29: 24$ & $\pi \alpha 1 \delta i ́ \sigma \kappa \eta$ \\
\hline Bilhah & $29: 29$ & $\pi \alpha_{1} \delta \dot{\delta} \sigma \kappa \eta$ \\
\hline Bilhah & $30: 3$ & $\pi \alpha_{1} \delta \dot{\delta} \sigma \kappa \eta$ \\
\hline Bilhah & $30: 4$ & $\pi \alpha \iota \delta i ́ \sigma \kappa \eta$ \\
\hline Bilhah & $30: 5$ & $\pi \alpha \iota \delta i ́ \sigma \kappa \eta$ \\
\hline Bilhah & $30: 7$ & $\pi \alpha 1 \delta i ́ \sigma \kappa \eta$ \\
\hline Zilpah & $30: 9$ & $\pi \alpha 1 \delta i ́ \sigma \kappa \eta$ \\
\hline Zilpah & $30: 10$ & $\pi \alpha_{1} \delta i ́ \sigma \kappa \eta$ \\
\hline Zilpah & $30: 12$ & $\pi \alpha 1 \delta i ́ \sigma \kappa \eta$ \\
\hline Bilhah & $35: 21$ & 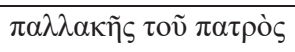 \\
\hline Bilhah & $35: 25$ & $\pi \alpha 1 \delta i ́ \sigma \kappa \eta$ \\
\hline Zilpah & $35: 26$ & $\pi \alpha 1 \delta i ́ \sigma \kappa \eta$ \\
\hline Zilpah/Bilhah & $37: 2$ & 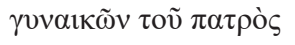 \\
\hline Zilpah & $46: 18$ & Just names \\
\hline Bilhah & $46: 25$ & Just names \\
\hline
\end{tabular}

(Genesis 16:423). Yet we do not see this problem with Zilpah and Bilhah. Though Rachel, Leah, and Sarai, all have handmaids that are given to their husbands as "wives" when they are unable to have children, the contexts of these situations differ. Zilpah and Bilhah did not use their pregnancies to "look down upon" their mistresses in the way that Hagar did. This marks a difference between the desires of Hagar, Zilpah and Bilhah.

23 Genesis 16:4: And he went in to Agar, and she conceived, and saw that she was with child, and her mistress was dishonoured before her. 
In Genesis $33: 2^{24}$, the narrator refers to Zilpah and Bilhah as the "two maids", and again in Genesis 33:6 simply as maids. In Genesis 37:26 however, as discussed previously, Zilpah and Bilhah are referred to as "wives" of Jacob. In Genesis 46:18 27 and $25^{28}$, though Zilpah and Bilhah are not referred to as maids here, it is explicitly mentioned after their names that Laban gave Zilpah and Bilhah to Leah and Rachel, respectively. This contradiction further proves that there was not a clear or certain upgrade in status for Zilpah and Bilhah simply because they give birth when they were given to Jacob as wives.

After this, Zilpah and Bilhah are mostly discussed in passing, although Bilhah is also mentioned in Genesis 35:22: "and Rueben went, and laid with Bilhah, his father's

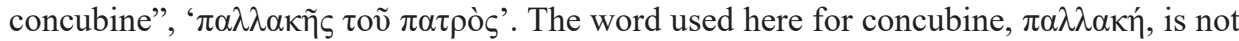
synonymous with wife. According to the Theological Dictionary of the Old Testament, "a concubine had a lower social status than a wife." ${ }^{29}$. Because Rachel and Leah gave Bilhah and Zilpah to Jacob, the status of Bilhah and Zilpah is still secondary to that of the wives of Jacob. ' $\pi \alpha \lambda \lambda \alpha \kappa \eta$ ' is also used in Genesis 25:5-6: "Now Abraham gave all that he had to Isaac; but to the sons of his concubines, Abraham gave gifts while he was still living, and sent them away from his son Isaac eastward, to the land of the east." The sons of Jacob's concubines clearly do not receive as much inheritance as his son Isaac, further enforcing the idea that concubines - and their offspring - were of a lower status than a wife.

Genesis 37:2 states, "Joseph, when seventeen years of age, was pasturing the flock with his brothers while he was still a youth, along with the sons of Bilhah and the sons of Zilpah, his father's wives". Here, the author refers to Bilhah and Zilpah as

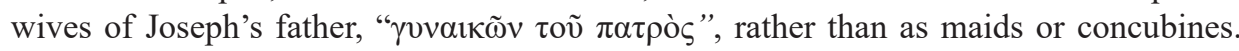
Additionally, Bilhah and Zilpah are referred to by name and are still associated with the children to which they gave birth (they are not considered Rachel's and Leah's children).

According to Gerhard Von $\operatorname{Rad}^{30}$, this practice of obtaining an heir through a proxy wife was common throughout Mesopotamian history. In these cultures, a wife would often bring her own personal maid into the marriage. Von Rad explains that, "If

24 Genesis 33:2: And he put the two handmaidens and their children with the first, and Lea and her children behind, and Rachel and Joseph last.

25 Genesis 33:6: And the maid-servants and their children drew near and did reverence

26 Genesis 37:2: And Joseph was seventeen years old, feeding the sheep of his father with his brethren, being young; with the sons of Balla, and with the sons of Zelpha, the wives of his father; and Joseph brought to Israel their father their evil reproach.

27 Genesis 46:18: These are the sons of Zelpha, which Laban gave to his daughter Lea, who bore these to Jacob, sixteen souls.

28 Genesis 46:25: These are the sons of Balla, whom Laban gave to his daughter Rachel, who bore these to Jacob; all the souls, seven.

29 Botterweck, Ringgren, and Fabry, 2001, 550.

30 Von Rad, 1972. 
she gave her personal maid to her husband, in the event of her own childlessness, then the child born of the maid was considered the wife's child: The slave was born 'on the knees' of the wife, so that the child then came symbolically from the womb of the wife herself." ${ }^{31}$.

Yet, a close examination of Genesis does not support the opinion that children birthed by handmaids are considered to be children of the wives. Even though the giving of maids for the intention of having children may have been traditional, it does not seem to be the case that these children born from maids belong to the wives. This is clear from the fact that, after Bilhah bears two children, Rachel still tries to have a biological child, which is demonstrated by her effort to obtain the mandrakes from Reuben for giving birth. (Genesis 30:1432). Furthermore, Genesis 33, 37, and 46 clearly specify that the children born in Genesis 30 belong to the woman who bore them.

According to Genesis 33:2-3, Jacob "divided the children among Leah and Rachel and the two maids. He put the maids with their children in front, then Leah with her children, and Rachel and Joseph last of all." This same grouping is restated in Genesis 33:6. The children are grouped and distinguished by the women who bore them. Though the maids are not named here, they are still identified as the mothers of Jacob's children.

Genesis 46 provides the lineage of Jacob's sons and who bore them. As with the other examples, the children birthed by the maids are not counted towards the children birthed by his wives. Genesis $46: 8-15^{33}$ lists the sons biologically born from Leah. Then, Genesis $46: 16-18^{34}$ lists the sons born to Zilpah. In 46:1935, Rachel is only listed with the two sons she bore herself - Joseph and Benjamin. The sons born to Bilhah are listed

31 Von Rad, 1972, 191.

32 Genesis 30:14: And Ruben went in the day of barley-harvest, and found apples of mandrakes in the field, and brought them to his mother Lea; and Rachel said to Lea her sister, Give me of thy son's mandrakes.

33 Genesis 46:8-15: And these are the names of the sons of Israel that went into Egypt with their father Jacob-Jacob and his sons. The first-born of Jacob, Ruben. And the sons of Ruben; Enoch, and Phallus, Asron, and Charmi. and the sons of Symeon; Jemuel, and Jamin, and Aod, and Achin, and Saar, and Saul, the son of a Chananitish woman. And the sons of Levi; Gerson, Cath, and Merari. And the sons of Judas; Er, and Aunan, and Selom, and Phares, and Zara: and Er and Aunan died in the land of Chanaan. And the sons of Phares were Esron, and Jemuel. And the sons of Issachar; Thola, and Phua, and Asum, and Sambran. And the sons of Zabulun, Sered, and Allon, and Achoel. These are the sons of Lea, which she bore to Jacob in Mesopotamia of Syria, and Dina his daughter; all the souls, sons and daughters, thirty-three.

34 Genesis 46:16-18: And the sons of Gad; Saphon, and Angis, and Sannis, and Thasoban, and Aedis, and Aroedis, and Areelis. And the sons of Aser; Jemna, Jessua, and Jeul, and Baria, and Sara their sister. And the sons of Baria; Chobor, and Melchiil. These are the sons of Zelpha, which Laban gave to his daughter Lea, who bore these to Jacob, sixteen souls.

35 Genesis 46:19: And the sons of Rachel, the wife of Jacob; Joseph, and Benjamin. 


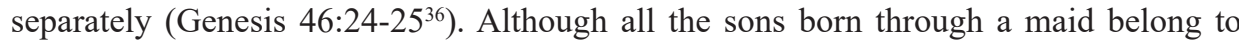
Jacob's lineage, they do not have the status of the sons birthed by the original wife. This could explain why Rachel changes her mind and decides that she wants to have a biological child in Genesis 30. She probably does not want to be the only woman in the house without children.

Rachel, Leah, Bilhah, and Zilpah also tend to be treated together as an indivisible group. Despite that, they enjoy no intimacy but, instead, quarrel and bicker incessantly. Only once do they cooperate: when they feel that Laban has robbed their children of their rightful inheritance they act with their husband against their father (Genesis 31$)^{37}$. According to Silverman Kramer, biblical women are frequently depicted in pairs but they are rarely depicted as friends. The Bible contains single, non-paired women who are dynamic, intense, unmarried individuals involved in vivid sexual misconduct of unusual proportions, or sin, or tragedy. ${ }^{38}$

Moreover, Zilpah and Bilhah do not seem to be eponymous figures nor are they connected with any clear mythological stories. The incest of Reuben with Bilhah may possibly belong to the class of fecundating incest that is associated with Adonis, who is the son of Cinyras by incestuous intercourse with his daughter Myrrha or Smyrna ${ }^{39}$. The chief heir sometimes attempted to usurp the patriarch's authority during the latter's lifetime. Reuben unsuccessfully attempted to assert his control by possessing his father's concubine, Bilhah. ${ }^{40}$

Another issue that needs to be mentioned is the different interpretations of Bilhah and Zilpah in some rabbinical commentary. For example, according to the early rabbinical commentary Pirke De-Rabbi Eliezer ${ }^{41}$, Zilpah and Bilhah were actually younger daughters of Laban ${ }^{42}$. Another example of mention of the two women outside of the bible is from Rashi ${ }^{43}$, an $11^{\text {th }}$ century commentator, who said that Zilpah was younger than Bilhah. Laban's decision to give her to Leah was all part of tricking Jacob into marrying Leah.

36 Genesis 46:24-25: And the sons of Nephthalim; Asiel, and Goni, and Issaar, and Sollem. These are the sons of Balla, whom Laban gave to his daughter Rachel, who bore these to Jacob; all the souls, seven.

37 Brenner, 1986, 263.

38 Kramer, 1998, 219.

39 Albright, 1918, 117.

40 Spanier, 1989, 126.

41 Haggadicmidrashic work on Genesis, part of Exodus, and a few sentences of Numbers; ascribed to R. Eliezer b. Hyrcanus and composed in Italy shortly after 833.

42 Friedlander, 1916, 271-272.

43 Rashi (Rabbi Solomon ben Isaac, 1040-1105) is considered the greatest Jewish scholar of medieval times in Ashkenaz (Germany, France and England) 
The genealogy of Bilhah and Zilpah is not discussed in the Hebrew Bible. In the Greek Testaments of the Twelve Patriarchs a Testament of Naphtali (TPN) ${ }^{44}$ can be found. (Table 3) In it, Naphtali first tells of his own birth by Bilhah and his relationship to Rachel (TPN 1:6-8 $)^{45}$. He then goes on to relate his mother's family origins as follows:

TPN 1:9 And my mother is Bilhah the daughter of Rotheus, a brother of Debora, Rebecca's nurse who was born the same day as Rachel.

TPN 1:10 And Rotheus was of the family of Abraham, a Chaldean, Godfearing, freeborn and noble.

TPN 1:11 And after having been taken captive he was bought by Laban, and he gave him Aina his servant to wife who bore him a daughter and she called her name Zilpah, after the name of the village where he had been taken captive.

TPN 1:12 Next she bore Bilhah, saying: My daughter is eager for what is new; for immediately after she was born she was eager to suck

\section{DEPICTION of ZILPAH and BILHAH in CHRISTIAN ART}

This section specifically examines artistic representations of Bilhah and Zilpah - some well-known and others lesser known. Discovering how, and of what status, the handmaids were represented in art is the main purpose of this section.

Apparently, the earliest depiction of Zilpah and Bilhah is represented on fol. 124r, 138v (Fig. 1) in Cotton Genesis". The scenes of "Bilhah Given to Jacob" (Genesis 30: 3-4) and "Jacob Lying with Bilhah" (Genesis 30:4) are placed at the top of the page, following the text of Genesis 30:3 on the previous page. The "Birth of Dan" is proleptically placed immediately below it, though this art should have followed Genesis 30:5.

44 The material which was originally attributed to Testament of Naphtali and which was assigned to us consisted of two plates; PAM 43.237 contains three fragments and PAM 43.245 contains four fragments. However, closer examination uncovered the fact that these two plates contain two different documents; one is the so-called Testament of Naphtali (TN) while the other is a sectarian composition. On paleographic grounds, the manuscript on PAM 43.237 belongs at the very earliest to the late Hasmonean period, but it is probably better placed squarely in the Herodian period. Eleven lines of writing survive, one of which is empty and the last of which is very fragmentary. The text contains narrative about two incidents. The first is the genealogy, birth and naming of Bilhah and the second is apparently the story of how Laban gave Bilhah and Zilpah to Jacob. (Stone, 1996, 20)

45 Stone, 1996, 22.

46 Dated late fifth and sixth century. (Lowden, 1992, 41). 
Table 3: The Genealogy of Bilhah.

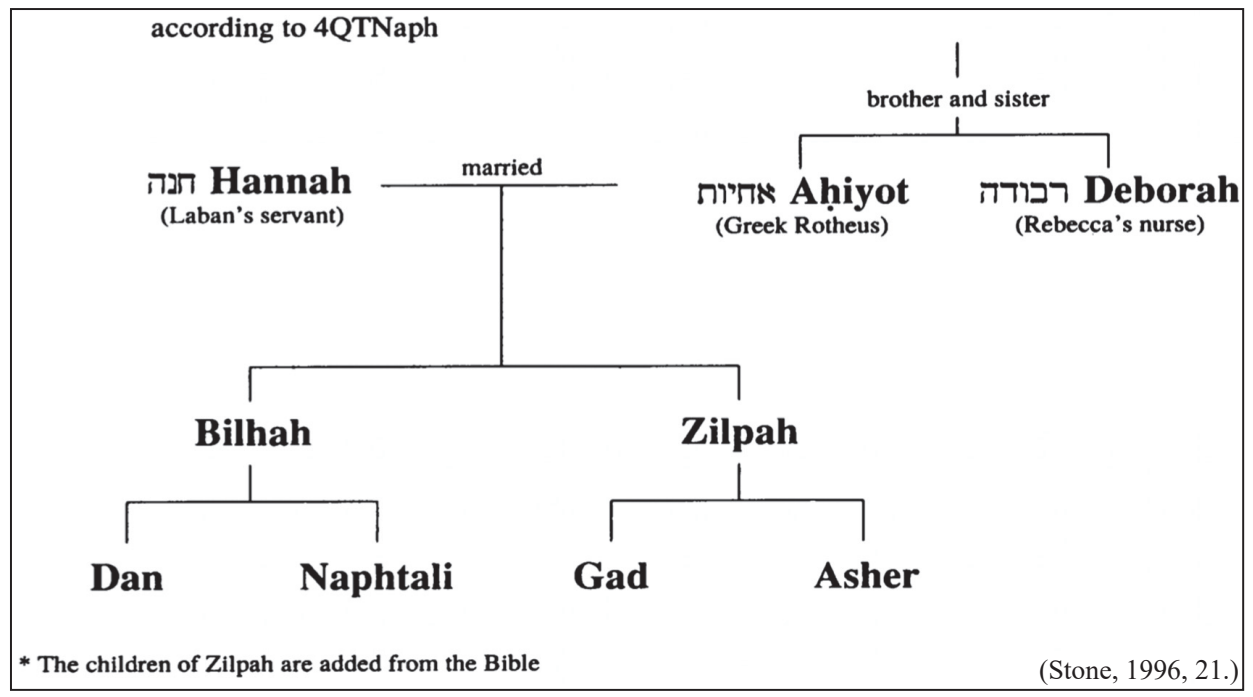

The remarkable paint of the two-tiered illustration remains. The upper register includes Rachel wearing a magenta palla over a white undergarment facing to the right and touching the elbow of Bilhah, who wears a vermilion and magenta garment. Bilhah stands three-quarters to the right. In the dark green doorway, indicated by gold traces around the door hinges, Jacob stands against the women. Only his head and traces of his vermilion garments remain. To the far right is the general form of a magenta mattress on a bed with indications of a figure lying on it. The lower register features a large, magenta mattress on gold legs, belonging to the birth scene ${ }^{47}$.

A similar example can be seen in Rovigo Bible in the Biblioteca dell'Accademia dei Concordi that was produced in Padua and is dated late 14th century ${ }^{48}$. Fol. 21v shows Bilhah Given to Jacob and fol. 22r shows Bilhah Giving Birth.

In the Cotton Genesis manuscript in fol. 124v (mounted sideways) and 138r, the Birth of Naphtali (Genesis 30: 7-8) and Zilpah Given to Jacob (Genesis 30:9) are illustrated at the top of the page. The leaf is badly fragmented, but the paint, though blistered, is legible. On the right, light brown lines, dark brown lines and gold highlights outline a door. A figure in a magenta garment stands to the left of the door. The head of a second figure is visible to the left of the first. These two figures are from the scene of Zilpah Given to Jacob. At the far left is a magenta form, certainly the mattress on which

47 Weitzmann and Kessler, 1986, 95.

48 Weitzmann and Kessler, 1986, 26. 


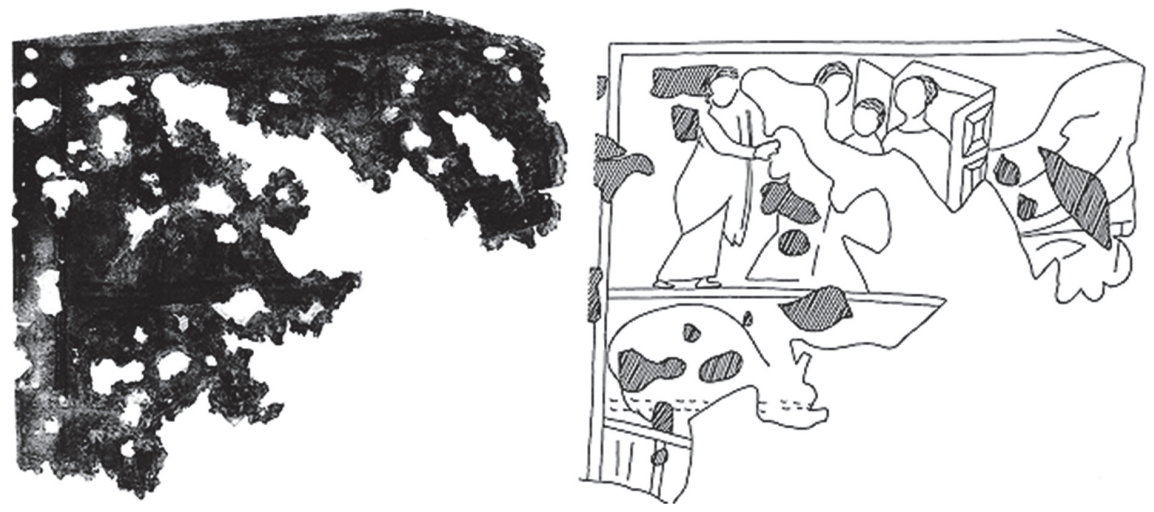

Fig. 1: Cotton Genesis, fol. 59v. (Weitzmann \& Kessler, 1986, fig. 306-307.)

Bilhah lies, and also traces of a midwife. The wall in the background is draped with magenta curtains, behind which a blue sky can be seen ${ }^{49}$.

In fol. 70r, the large, double miniature, which leaves space for only four lines of writing at the bottom of the page, illustrates events recounted on the previous leaf. In the upper register are Reuben's Intercourse with Bilhah and Isaac's Meeting with Jacob; in the lower zone are Isaac's Death and Burial ${ }^{50}$.

An unusual way of representing handmaids was chosen by the illuminator of fol. 15r (Fig. 2) of the Vienna Genesis, a Greek paraphrase of the book of Genesis from the 6th century. In the scene of Joseph's second dream, there is a woman near Jacob who cannot be identify with anyone in the biblical Genesis text. Because, according to Genesis, Rachel was already dead at this time, thus the identity of this figure is problematic. In the Midrash (84.II) that commentates Joseph's second dream, the author mentions Bilhah, Rachel's handmaid, who had brought Joseph up like a mother. According to this legend, the woman depicted standing next to Joseph and Jacob in fol. 15r (Fig. 2) of the Vienna Genesis must be Bilhah ${ }^{51}$.

Although in the text of fol. $10 \mathrm{v}$ it is indicated as two handmaids ${ }^{52}$, a single female figure is depicted in the "Laban goes into Jacob's tent and the tent of the two handmaids"

49 Weitzmann and Kessler, 1986, 95-96.

50 Weitzmann and Kessler, 1986, 101.

51 Levin, 1972, 241-242.

52 Was mentioned as "ПAI $\Delta \mathrm{I} \Sigma \mathrm{K} \Omega \mathrm{N}$ " [(fem) gen $\mathrm{pl}$ form $]$ in the text. 


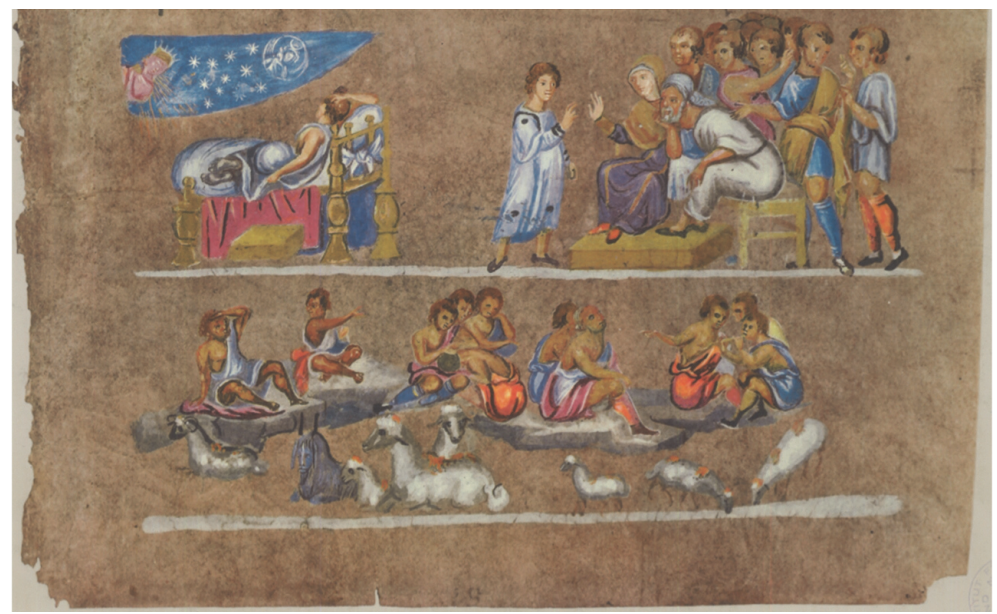

Fig. 2:

Vienna Genesis,

fol. 15 r.

(Mazal, 1980, p. 29.)

scene. In another example - fol. $12 \mathrm{r}$ - although the handmaids ${ }^{53}$ are mentioned in the text, there is no descriptive figure in the picture.

The ivory chair of bishop Maximian of Ravenna ${ }^{54}$ (Fig. 3) decorated with ivory panels represents narratives from the Old and New Testaments. The scene of Jacob Mourning, for example, is a compilation of varying expressive poses, including that of Jacob who, positioned in the center, is seen thrusting his hands above his head, wailing in pain over news of the death of Joseph. His wife (Zilpah or Bilhah) situated at the far right, is rendered in a particularly unique pose that typifies the individualism provided to figures on the cathedra: she sits, holding up her bent knee with her clasped hands, attentively listening to the tragic news.

The expressive positions of the characters are enhanced by the fact that all of the figures on the cathedra possess large, block-like hands that gesture emphatically. Generally, authors either show emotion or communicate a narrative. Thus, the use of this technique, having the block-like hands of these characters express both a narrative and emotion, is unique.

In the Smyrna Octateuch, fol. 43r (Fig. 4), the inscription reads: $\pi \alpha \rho \circ \chi \dot{\eta} \tau \tilde{\eta} \varsigma$

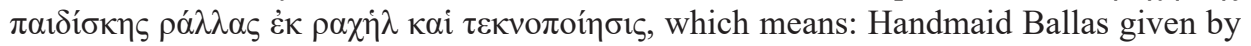
Rahel and childbirth. In the scene "Rachel Gives Bilhah to Jacob", Rachel, grieving that she has not borne Jacob any children, persuades her husband to have a child by her maid, Bilhah. Jacob stands in the center. Rachel at the right holds the hem of her mantle before her face in a gesture of grief or weeping while Jacob looks at Bilhah. The scene is framed

53 Was mentioned as "ПAI $\Delta \mathrm{I} \Sigma \mathrm{KA} \Sigma$ " [(fem) acc $\mathrm{pl}$ form] in the text.

54 Dated to $6^{\text {th }}$ centrury (Cutler, 1998, 11.) 


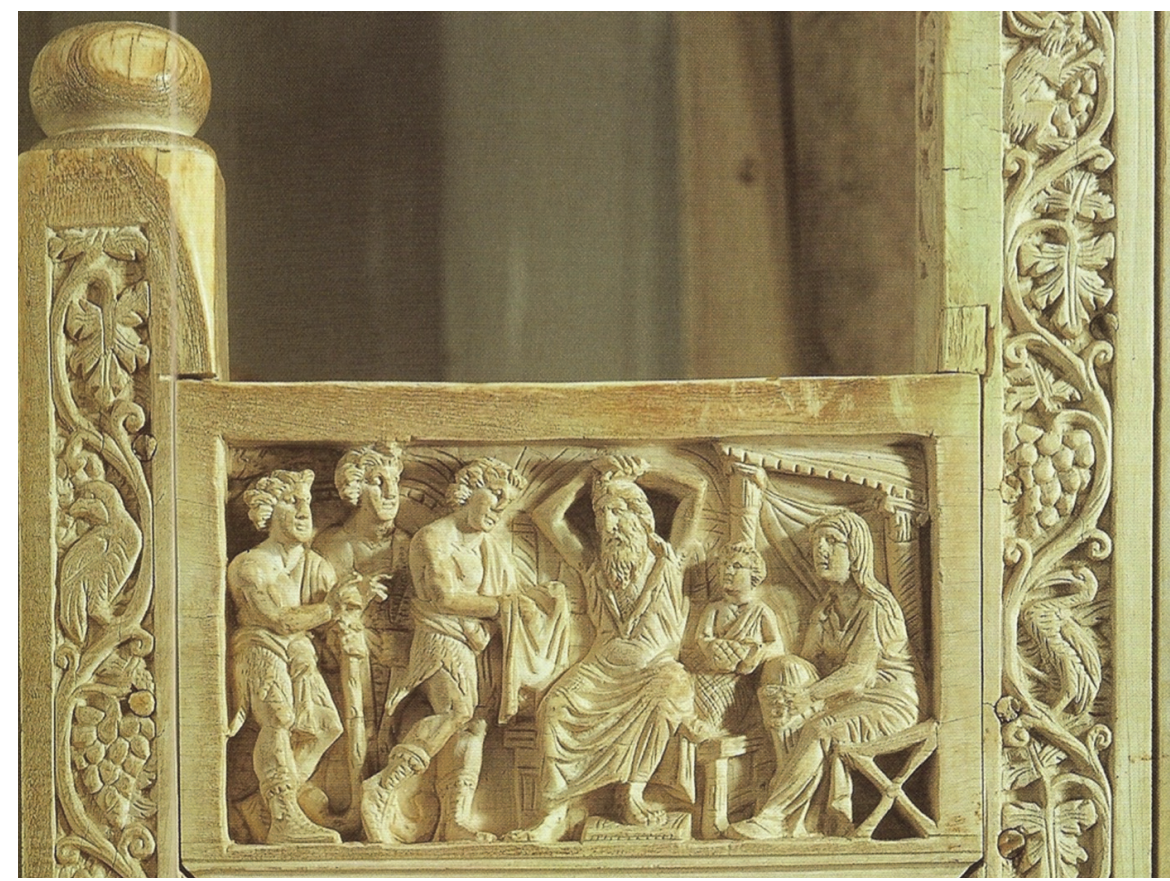

Fig. 3: Cathedra of Maximian, Jacob Mourning. (Luttikhuizen \& Verkerk, 2006, f. 4.50)

by a hillock on the left and a simple house on the right. Very similar scenes are seen in manuscripts of Codex Vaticanus Graecus 747; fol. 51v (Fig. 5), Seraglio Octateuch; fol. 107r and Codex Vaticanus Graecus 746; fol. 101r .55

\section{CONCLUSION}

In summary, in terms of the position of handmaids in the biblical Genesis text, it is possible that children may have increased the status of women in Genesis, but this is only true of women who already had status to speak of. Handmaids did not benefit from having children, as can be seen from Bilhah, Zilpah, and Hagar. As it is understood, the Bible does not focus on the variety of social positions that women have held. Handmaids, even if they had children on behalf of their mistress, did not receive an increase in status. Also, the status of the sons within the family is affected by the relative status of their

55 Weitzmann \& Bernabò, 1999, 104. 


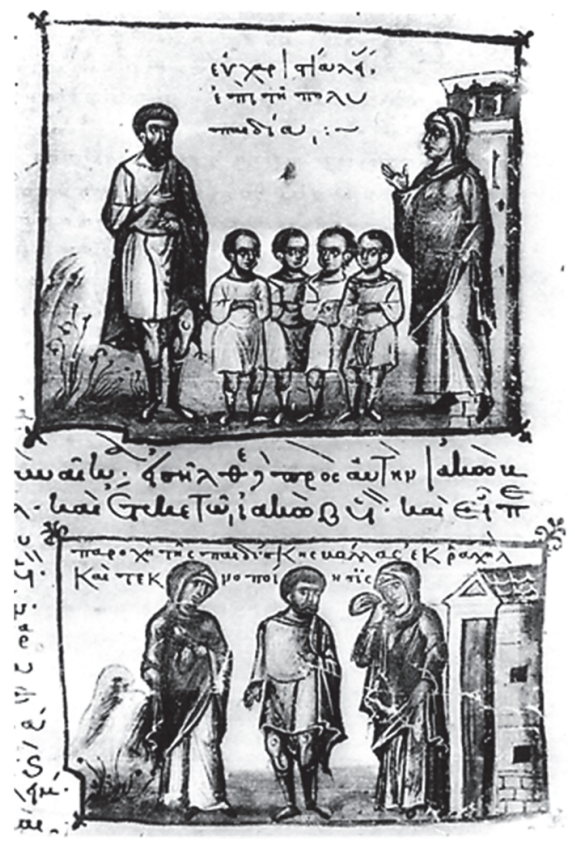

Fig. 4: Smyrna Octateuch, fol. 43r. (Weitzmann \& Bernabò, 1999, fig. 413.)

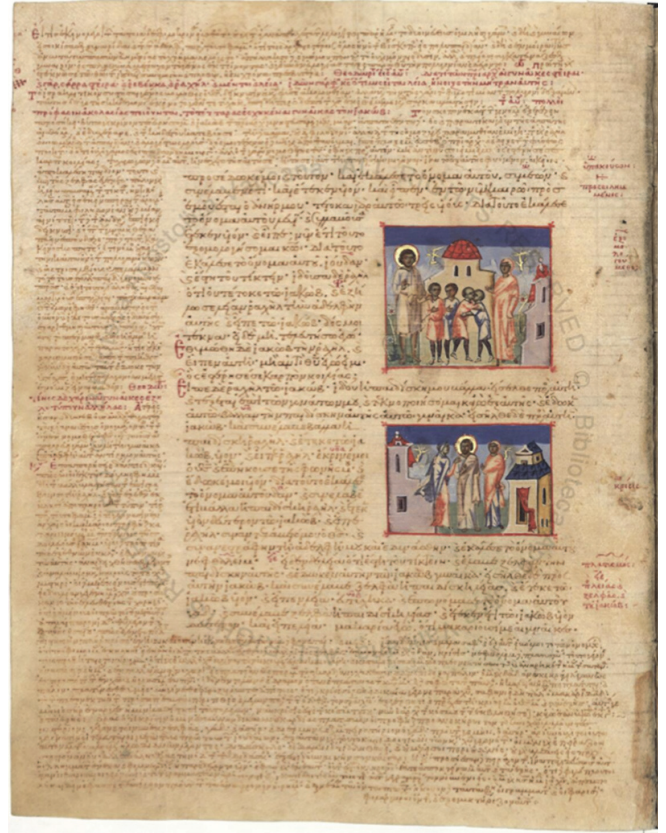

Fig. 5: Vat. Gr. 747, fol. 51v. (Biblioteca Apostolica Vaticana, https://digi.vatlib.it/view/MSS_Vat.gr.747)

mothers. When in danger, the less-favored wives/concubines and their children step into danger first (See Genesis 33:2). ${ }^{56}$

As a result, it is very rare that the handmaids in Jacob's Story are specifically depicted in Christian art. Looking at all the examples, it can be seen that Bilhah and Zilpah are depicted combined and individually. However, no specific descriptive element has been identified. Consequently, identifying the handmaids is only possible by following the chronological sequence of events in Genesis. One of the most important characteristics of the Vienna Genesis manuscript is that it was adorned with narrative scenes that are not found in the biblical Genesis text. In such cases, figuring out which story is depicted becomes a bigger problem than distinguishing identities.

56 Genesis 33:2 And he put the two handmaidens and their children with the first, and Lea and her children behind, and Rachel and Joseph last. 


\section{BIBLIOGRAPHY}

Albright W. F. (1918). Historical and Mythical Elements in the Story of Joseph. Journal of Biblical Literature. Vol. 37, No. 3/4, 111-143.

Block D. I. (2003). Marriage and Family in Ancient Israel. In Campbell, K. M. (Ed.). Marriage and Family in the Biblical World. pp. 33-103. USA: InterVasity Press.

Botterweck G. J., Ringgren H., \& Fabry H. J. (Ed.) (2001). Theological Dictionary of the Old Testament. Vol XI, Grand Rapids: William B. Eerdmans Publishing Company.

Brenner A. (1986). Female Social Behaviour: Two Descriptive Patterns within the "Birth of the Hero" Paradigm. Vetus Testamentum. Vol. 36, Fasc. 3, 257-273.

Cutler A. (1998). Late Antique and Byzantine Ivory Carving. Collected Studies, 617 Variorum.

Friedlander G. (Trans.) (1916). Rabbi Eliezer. Pirke De Rabbi Eliezer. London: Kegan Paul, Trench, Turner \& Co. Ltd.

Joslin M.C. \& Watson C.J. (2001). The Egerton Genesis. The British Library University of Toronto Press.

JWA Encyclopedia (https://jwa.org/encyclopedia/article/rashi)

Kramer, P. S.(1998). Biblical Women that Come in Pairs: The Use of Female Pairs as a Literary Device in the Hebrew Bible. (ed. Brenner A.) Genesis: A Feminist Companion to the Bible. FCB2 1; Sheffield: Sheffield Academic Press.

Leonhardt Joy K. (2004). And as for Sarai...” First Wives and the Inheritance of Land In the Promise Narratives of Genesis (Master of Arts). University of Alberta.

Levin D. M. (1972). Some Jewish Sources for the Vienna Genesis. The Art Bulletin. Vol. 54, No. 3, 241-244.

Liddell H. G. \& Scott R. (Ed.) (1901). Greek-English Lexicon. Oxford: Clarendon Press.

Lowden J. (1992). Concerning the Cotton Genesis and Other Illustrated Manuscripts of Genesis. Gesta, Vol. 31, No. 1, pp. 40-53. 
Luttikhuizen H. \& Verkerk D. (2006) Snyder's Medieval Art. 2nd ed., (Upper Saddle River, NJ: Prentice Hall.

Moss, C. R. \& Baden, J. S. (2015). Reconceiving Infertility Biblical Perspectives on Procreation and Childlessness. Princeton: Princeton University Press.

Potts, C. A. (1922). Dictionary of Bible Proper Names; Every Proper Name in the Old and New Testaments Arranged in Alphabetical Order; Syllabified and Accented; Vowel Sounds Diacritically Marked; Definitions Given in Latin and English. New York: Abingdon Press

Spanier, K. (1989). Aspects of Fratriarchy in the Old Testament (Ph.D. dissertation). New York University.

Stone, M. E. (1996). The Genealogy of Bilhah. Dead Sea Discoveries. Vol. 3, No. 1, 20-36.

Vatican Library (https://digi.vatlib.it/view/MSS_Vat.gr.747)

Von Rad G. (1972). Genesis A Commentary (Revised Edition). London: SCM Press LTD.

Weitzmann, K. \& Bernabò, M. (1999). The Byzantine octateuchs: Mount Athos, Vatopedi Monastery, codex 602; Florence, Biblioteca Medicea Laurenziana, Codex Pluteus 5.38; Istanbul, Topkapi Sarayi Library, codex G. I. 8; Rome, Biblioteca Apostolica Vaticana, Codex Vaticanus Graecus 746 and Codex Vaticanus Graecus 747; Smyrna (olim), Evangelical School Library, codex A. 1. Text. Princeton, NJ: Princeton Univ. Pr.

Weitzmann, K. \& Kessler, H. (1986). The cotton genesis: British Library, Codex Cotton Otho B. VI. Princeton. NJ: Princeton Univ. Press

Wevers, J. W. (1974). Septuaginta: Vetus Testamentum Graecum. 1. Genesis. Göttingen: Vandenhoeck \& Ruprecht. 
Ege Üniversitesi, Edebiyat Fakültesi

Sanat Tarihi Dergisi ISSN 1300-5707

Cilt: XXVII, Sayı: 2 Ekim 2018
Ege University, Faculty of Letters

Journal of Art History

e-ISSN 2636-8064

Volume: XXVII, Issue: 2 October 2018

Yavin Tarihi | Date of Publication

31.10 .2018

Internet Sayfası (Acık Erișim) | Internet Page (Open Access)

\section{DergiPark}

http://dergipark.gov.tr/std 